\title{
19. SEISMIC STRATIGRAPHY AND GEOLOGIC HISTORY OF THE RIO GRANDE GAP AND SOUTHERN BRAZIL BASIN ${ }^{1}$
}

\author{
Luiz A. Gamboa, ${ }^{2}$ Lamont-Doherty Geological Observatory of Columbia University, Palisades, New York \\ Richard T. Buffler, ${ }^{3}$ University of Texas Institute for Geophysics, Galveston, Texas \\ and \\ Peter F. Barker, Department of Geological Sciences, Birmingham University, Birmingham B15 2TT, England
}

\begin{abstract}
The sedimentary evolution of the Rio Grande Gap and southern portion of the Brazil Basin has been reconstructed by the analysis of single-channel and multichannel seismic reflection profiles. Conspicuous erosional and depositional episodes identified from the seismic records are dated by cores recovered from Site 515 located to the north of the Vema Channel. A major erosional event, marked by a 22-Ma hiatus, occurred between the early Eocene and middle Oligocene. This erosional event is tentatively associated with the initiation of the flow of Antarctic Bottom Water (AABW) through the Rio Grande Gap and into the Brazil Basin. After AABW started to flow, the net sediment accumulation in the Rio Grande Gap and southern part of the Brazil Basin was small until the latest Oligocene, when large amounts of sediment began to accumulate in these areas. The Vema Channel was formed in the latest Oligocene when these sediments began to infill the Rio Grande Gap. This high influx of sediments occurred concomitantly with a major low stand of sea level. The lowered sea level allowed large quantities of terrigenous sediments to reach the lower continental rise and abyssal plain of the Argentine Basin and from there to be transported northward by AABW. Sediments that bypassed the Rio Grande Gap, mainly through the Vema Channel, formed a large fanlike deposit at the southern portion of the Brazil Basin.
\end{abstract}

\section{INTRODUCTION}

This paper presents the results of a seismic study in the Rio Grande Gap and in the adjacent southern part of the Brazil Basin. The Rio Grande Gap is a topographic depression between basement highs that separate the Argentine Basin from the Brazil Basin (Fig. 1). The Vema Channel, within the Rio Grande Gap, is the major passage through which Antarctic Bottom Water (AABW) now flows north from the Argentine Basin into the Brazil Basin. The objectives of this seismic study were: (1) to investigate the geologic history of this area by use of seismic stratigraphic techniques; (2) to date the beginning of AABW flow through the Rio Grande Gap; and (3) to understand how the northward flow of bottom water is related to the origin of the Vema Channel and to the sedimentary sequences underlying the Rio Grande Gap and the southern part of the Brazil Basin.

The data used in this study include: (1) multichannel seismic reflection profiles obtained by the University of Texas Institute for Geophysics, as part of a DSDP sitesurvey cruise; (2) single-channel seismic reflection profiles obtained by Lamont-Doherty Geological Observatory of Columbia University during the past fifteen years, and (3) the results of drilling at DSDP Site 515 (Fig. 2).

\section{GENERAL SETTING}

The major topographic features of the continental margin off southern Brazil and of the adjacent oceanic

\footnotetext{
${ }^{1}$ Barker, P. F., Carlson, R. L., Johnson, D. A., et al., Init. Repts. DSDP, 72: Washington (U.S. Govt. Printing Office).

2 Present address: Center for Marine Crustal Studies, Gulf Science and Technology, Pearl River, New York.

3 Present address: The University of Texas, Austin, Texas.
}

basin strongly affect the circulation of the deep water. These large basement features include the São Paulo Ridge, the Rio Grande Rise, and the subdued basement high lying to the west of the Rio Grande Rise (Gamboa, 1981, and Fig. 3). These morphologic features govern the flow of two deep-water masses: (1) the southwardflowing North Atlantic Deep Water (NADW) and (2) the northward-flowing Antarctic Bottom Water (AABW). NADW flows south along the Brazilian continental rise and sweeps the margins of the Rio Grande Rise and tìe main surface of the São Paulo Plateau (Gamboa and Kumar, 1977). AABW flows northward beneath NADW and enters the Brazil Basin mainly through the Vema Channel, located within the Rio Grande Gap (Wüst, 1957; Wright, 1970; LePichon et al., 1971; Melguen and Thiede, 1974; Johnson et al., 1976; Ledbetter and Johnson, 1976; Damuth and Hayes, 1977; Lawrence, 1979) (Fig. 1). A smaller volume of AABW also flows into the Brazil Basin via a trough parallel to the southern face of the São Paulo Ridge and west of the Rio Grande Gap (Gamboa and Kumar, 1977, and Fig. 1). The basement relief of the Rio Grande Rise and São Paulo Ridge thus blocks large volumes of the north-flowing AABW and confines its flow to these two narrow channels, which constrict and accelerate the AABW flow and thus create a unique setting for deep-sea erosion and deposition.

\section{PREVIOUS INTERPRETATIONS OF SEISMIC DATA}

Using single-channel seismic reflection profiles, Le Pichon and others (1971) traced a pronounced seismic reflector throughout the Rio Grande Gap area and correlated it with the reflector (Horizon $\mathrm{A}$ ) that underlies the Argentine Basin (Ewing and others, 1964). In both 


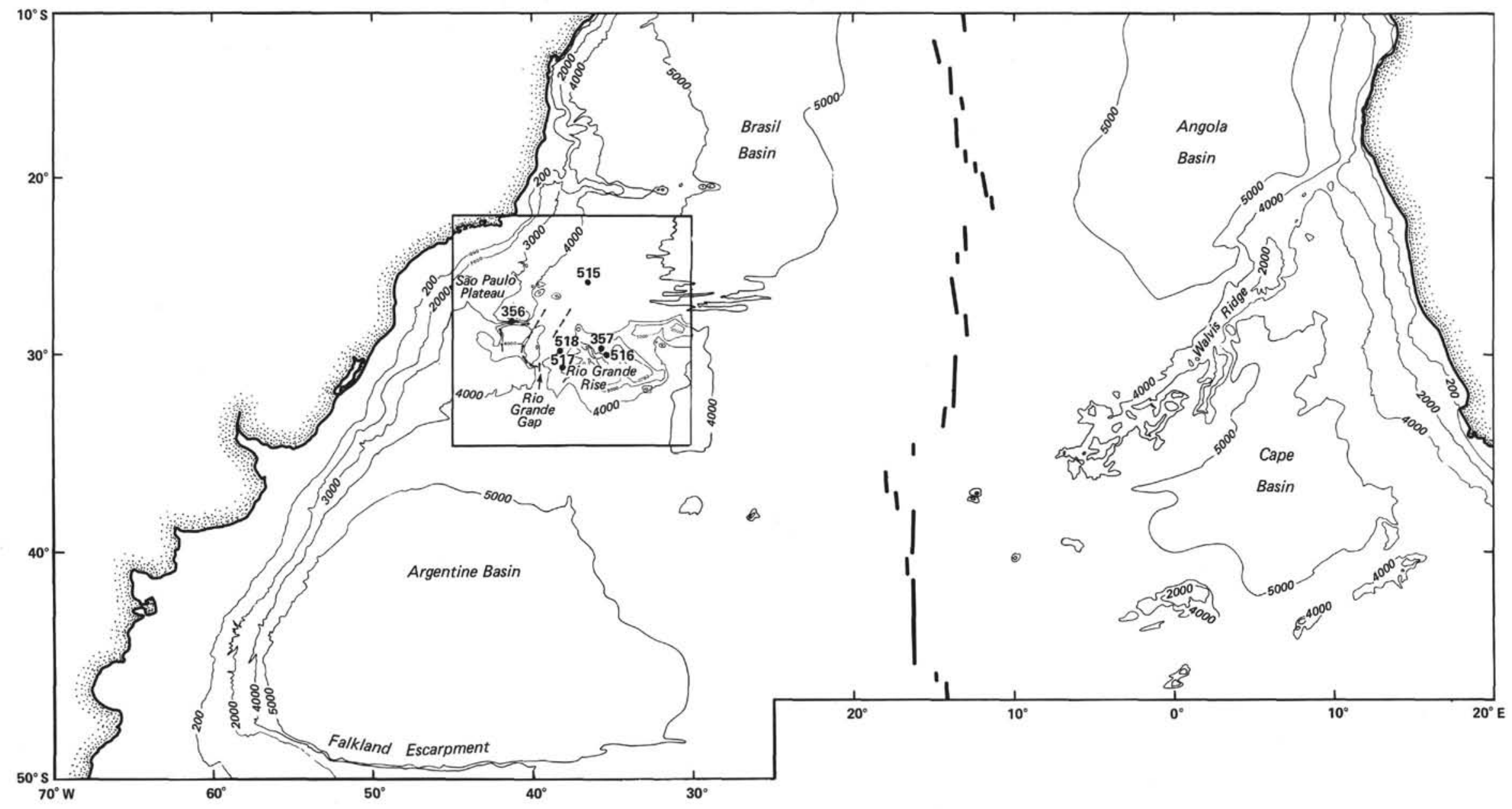

Figure 1. Location and bathymetry of the Rio Grande Gap and adjacent region from Heezen and Tharp (1978) and Moody and others (1979). Arrows mark the main pathways of Antarctic Bottom Water from the Argentine Basin to the Brazil Basin. 


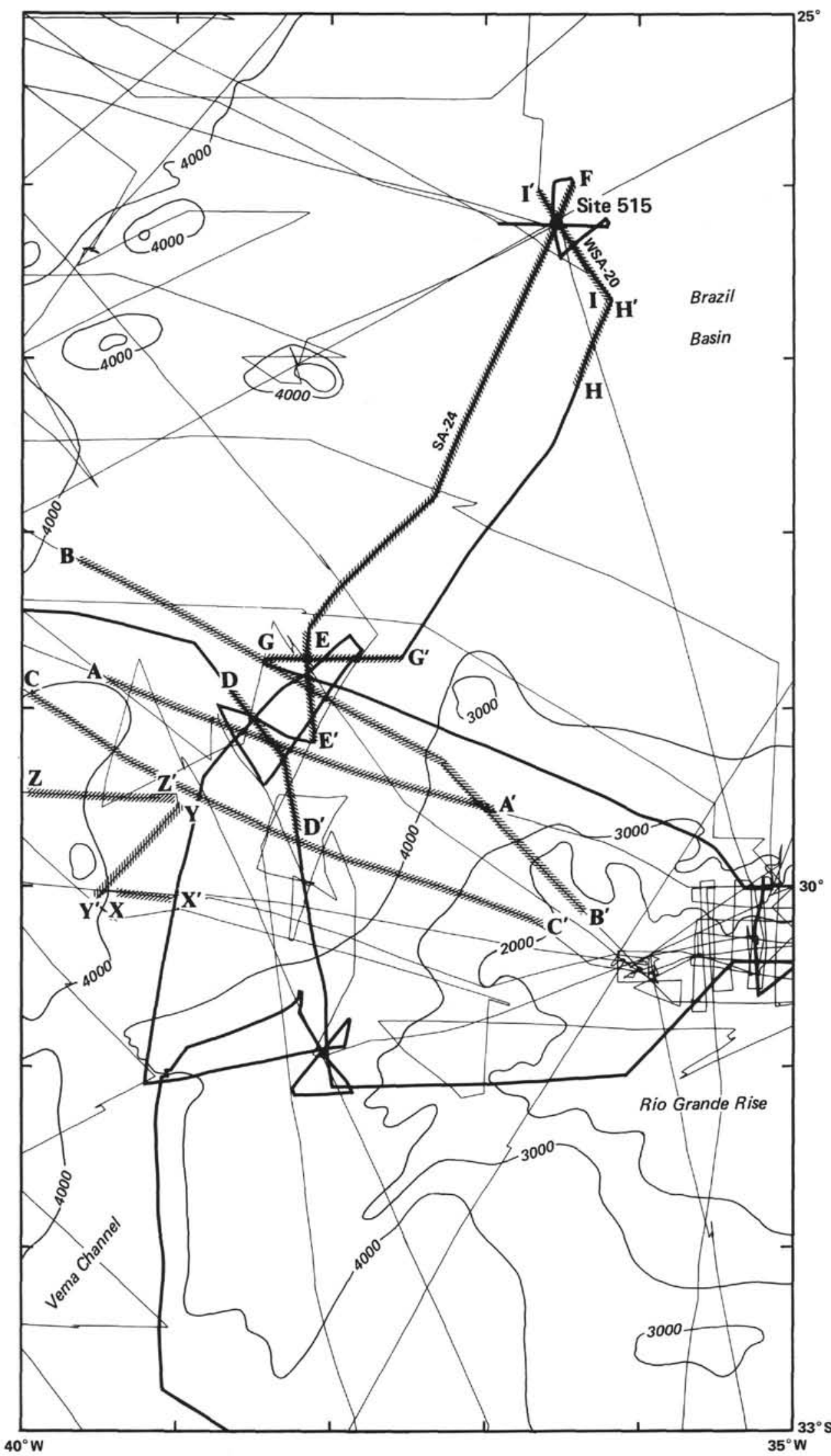

Figure 2. Location of the seismic profiles used in this study. Heavy lines indicate the multichannel profiles shot aboard the Fred H. Moore, other lines are single-channel seismic profiles shot aboard the Vema, Robert D. Conrad, and Glomar Challenger. Profiles shown in figures below are labeled along tracks. 


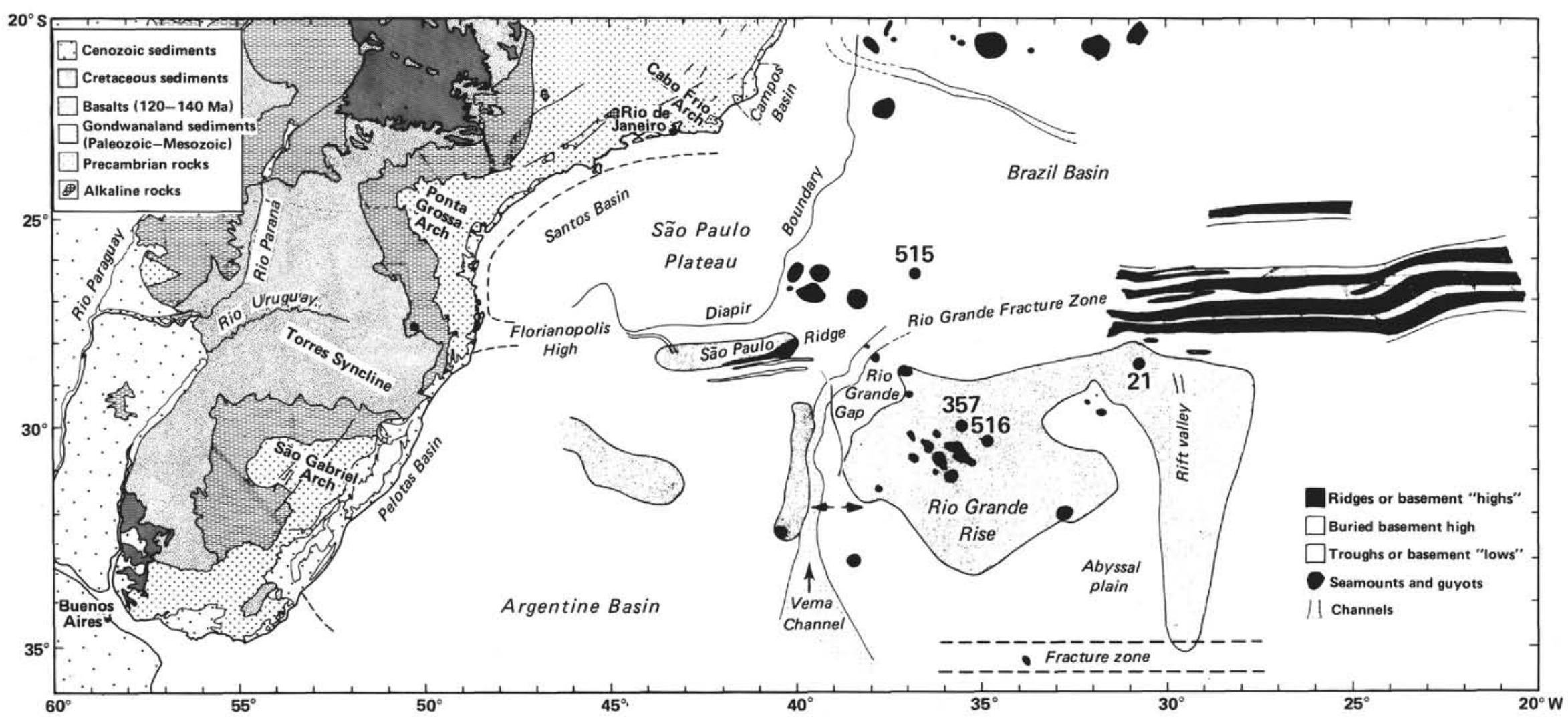

Figure 3. Structural map of the southern Brazilian continental margin and adjacent oceanic basin, showing the location of the Rio Grande Gap in relation to major tectonic features. 
the Argentine Basin and the Rio Grande Gap, Horizon A separates a thick sequence of acoustically transparent sediments from an overlying sequence of highly stratified sediments. This change in character was thought to have resulted from a marked change in the depositional processes, probably related to the beginning of circulation of AABW. Horizon A of the Argentine Basin was tentatively correlated with a similar reflector in the North Atlantic, which was dated as Cretaceous (Ewing and others, 1966 and 1971). However, Tucholke (1979) has shown that in the western North Atlantic, Horizon A is not a single reflector, but rather consists of a group of reflecting surfaces of diverse nature and ages varying from Maestrichtian (Cretaceous) to Oligocene. In addition, Zimmerman and others (1979) have dated Horizon $\mathrm{A}$ at Site 358 in the northern Argentine Basin as late Oligocene but considered it diagenetic in origin, and therefore potentially time-transgressive. As will be shown below, multichannel seismic data in the Rio Grande Gap indicate that actually two prominent reflectors or unconformities correspond to the horizon previously identified as Horizon A in the Argentine Basin. Because of this new information, correlation of reflectors in the $\mathrm{Ar}$ gentine Basin with those recognized in the Rio Grande Gap during the present study is uncertain.

\section{METHODS}

In June and July, 1979, the University of Texas Institute for Geophysics (UTIG), using Fred Moore, collected multichannel seismic data in the Rio Grande Gap and at the southern end of the Brazil Basin during surveys of sites to be drilled during DSDP/IPOD Leg 72 (Fig. 2). These multichannel seismic data enabled us to: (1) define a seismic stratigraphic framework for the area, (2) relate the prominent seismic sequences to the sediments sampled at DSDP Site 515, and (3) propose a model for the sedimentary evolution of the area. For seismic stratigraphic analysis, we used the approach developed by Vail and others (1977), which employs the seismic sequence as the basic stratigraphic unit.

\section{RESULTS}

\section{Seismic Stratigraphy in the Rio Grande Gap Area}

The Rio Grande Gap is a basement and topographic low with an average width of $150 \mathrm{~km}$, located between the Rio Grande Rise and a basement high to the west (Fig. 3). LePichon and others (1971) used the name Vema Gap to describe this feature, but we follow the designation Rio Grande Gap proposed by Maurer and Stocks (1933), because the name Vema Gap has also been used by Heezen and others (1959) to describe a passage between the Hatteras Abyssal Plain and the Nares Abyssal Plain in the northwestern Atlantic.

The Vema Channel lies within the Rio Grande Gap close to its western edge, and the Vema Terrace extends from the Vema Channel to the base of the Rio Grande Rise in the east (Figs. 4, 6-7). The floor of the Vema Channel is, on the average, $700 \mathrm{~m}$ lower than the terrace (Fig. 4). Except where the channel is in contact with the basement high (as seen in Fig. 7), the steeper wall of the Vema Channel always lies on the eastern side and the gentler slope along the western flank.

Analyses of the UTIG multichannel seismic data in the Rio Grande Gap area allow us to subdivide the sedimentary cover of this region into four seismic sequences, A through D, from the base to the top (Table 1 and Fig. 5). The sedimentary cover in the gap is about $1.2 \mathrm{~km}$ thick and lies on a strong reflector inferred to be the top of the oceanic crust. In general, this reflector is fairly smooth, but in places considerable relief is observed, which appears to indicate offset by faulting. On some multichannel lines, faint dipping reflectors can be observed within basement and may be indicative of layering within the volcanic rocks that constitute the upper portion of the oceanic crust (Figs. 5-6).

Sequence $\mathbf{A}$ is characterized by weak (relatively lowamplitude), continuous subparallel reflections. The lower part of this sequence onlaps and fills the relief on the basement, suggesting deposition by currents (Fig. 5 and Table 1). This unit corresponds to the acoustically transparent zone observed above the basement in the previously collected single-channel profiles (Figs. 4-5). The upper limit of Sequence $\mathbf{A}$ is defined by a prominent regional unconformity (Unconformity A), which truncates this sequence at several places. Where the basement high to the west of the Vema Channel is prominent, Unconformity A defines a paleochannel under the

Table 1. Stratigraphic correlation between the Rio Grande Gap and the southern Brazil Basin.

\begin{tabular}{|c|c|c|c|c|c|c|c|c|}
\hline \multicolumn{4}{|c|}{ Rio Grande Gap } & \multicolumn{5}{|c|}{ Brazil Basin } \\
\hline $\begin{array}{l}\text { Seismic } \\
\text { sequence }\end{array}$ & Unconformity & $\begin{array}{c}\text { Seismic } \\
\text { characteristics }\end{array}$ & $\begin{array}{l}\text { Depositional } \\
\text { setting }\end{array}$ & $\begin{array}{l}\text { Seismic } \\
\text { sequence }\end{array}$ & $\begin{array}{l}\text { Lithologic unit } \\
\text { at } 515\end{array}$ & Unconformity & $\begin{array}{c}\text { Seismic } \\
\text { characteristics }\end{array}$ & $\begin{array}{l}\text { Depositional setting } \\
\text { and inferred age }\end{array}$ \\
\hline D & \multirow{2}{*}{ C } & $\begin{array}{l}\text { Horizontal low-amplitude } \\
\text { reflections, locally onlap- } \\
\text { ping at base }\end{array}$ & $\begin{array}{l}\text { Sediments deposited under the } \\
\text { infuence of slow-moving } \\
\text { deep-sea currents }\end{array}$ & $\mathrm{v}$ & 1 & \multirow{2}{*}{ IV } & $\begin{array}{l}\text { Mostly acoustically } \\
\text { transparent }\end{array}$ & $\begin{array}{l}\text { Hemipelagic and settling of fine- } \\
\text { grained sediments carried in } \\
\text { suspension by the AABW; } \\
\text { Quaternary to early Pliocene or } \\
\text { late Miocene }\end{array}$ \\
\hline C & & $\begin{array}{l}\text { Channelward-dipping and } \\
\text { contorted reflections }\end{array}$ & $\begin{array}{l}\text { Prograding and slumping sed- } \\
\text { iments deposited by fast- } \\
\text { moving deep-sea currents; } \\
\text { analogous to a point-bar } \\
\text { sequence }\end{array}$ & IV & 2 & & $\begin{array}{l}\text { Lens-shaped body with strong } \\
\text { hummocky reflections at its } \\
\text { base \& acoustically transparent } \\
\text { towards the top }\end{array}$ & $\begin{array}{l}\text { High depositional rates under influ- } \\
\text { ence of strong currents, forming } \\
\text { a drift deposit in the deep sea; } \\
\text { middle Miocene to early Miocene } \\
\text { or late Oligocene }\end{array}$ \\
\hline B & B & $\begin{array}{l}\text { Mostly acoustically trans- } \\
\text { parent }\end{array}$ & $\begin{array}{l}\text { Areally restricted sedimenta- } \\
\text { tion within the gap under } \\
\text { the influence of bottom } \\
\text { currents }\end{array}$ & III & 2 & \multirow[t]{2}{*}{ II } & $\begin{array}{l}\text { Very thin sequence, areally re- } \\
\text { stricted in occurrence }\end{array}$ & $\begin{array}{l}\text { Deposition under strong currents, } \\
\text { filling a broad channel; late } \\
\text { Oligocene }\end{array}$ \\
\hline \multirow[t]{3}{*}{ A } & & $\begin{array}{l}\text { Low-amplitude, continuous } \\
\text { subparallel reflections, } \\
\text { onlapping at the base }\end{array}$ & $\begin{array}{l}\text { Hemipelagic sedimentation } \\
\text { over oceanic crust }\end{array}$ & II & 3 & & $\begin{array}{l}\text { Mostly acoustically transparent, } \\
\text { few subparallel continuous } \\
\text { weak reflections }\end{array}$ & $\begin{array}{l}\text { Hemipelagic sedimentation with } \\
\text { some bottom currents; early Eo- } \\
\text { cene to (?) }\end{array}$ \\
\hline & & \multirow[t]{2}{*}{ Basement } & & 1 & $\begin{array}{l}\text { Not } \\
\text { drilled }\end{array}$ & & $\begin{array}{l}\text { Low-amplitude subparallel reflec- } \\
\text { tions, some onlapping onto } \\
\text { basement }\end{array}$ & $\begin{array}{l}\text { Distal turbidites and hemipelagic } \\
\text { sedimentation; age unknown }\end{array}$ \\
\hline & & & & & & & Basement & Late Cretaceous \\
\hline
\end{tabular}



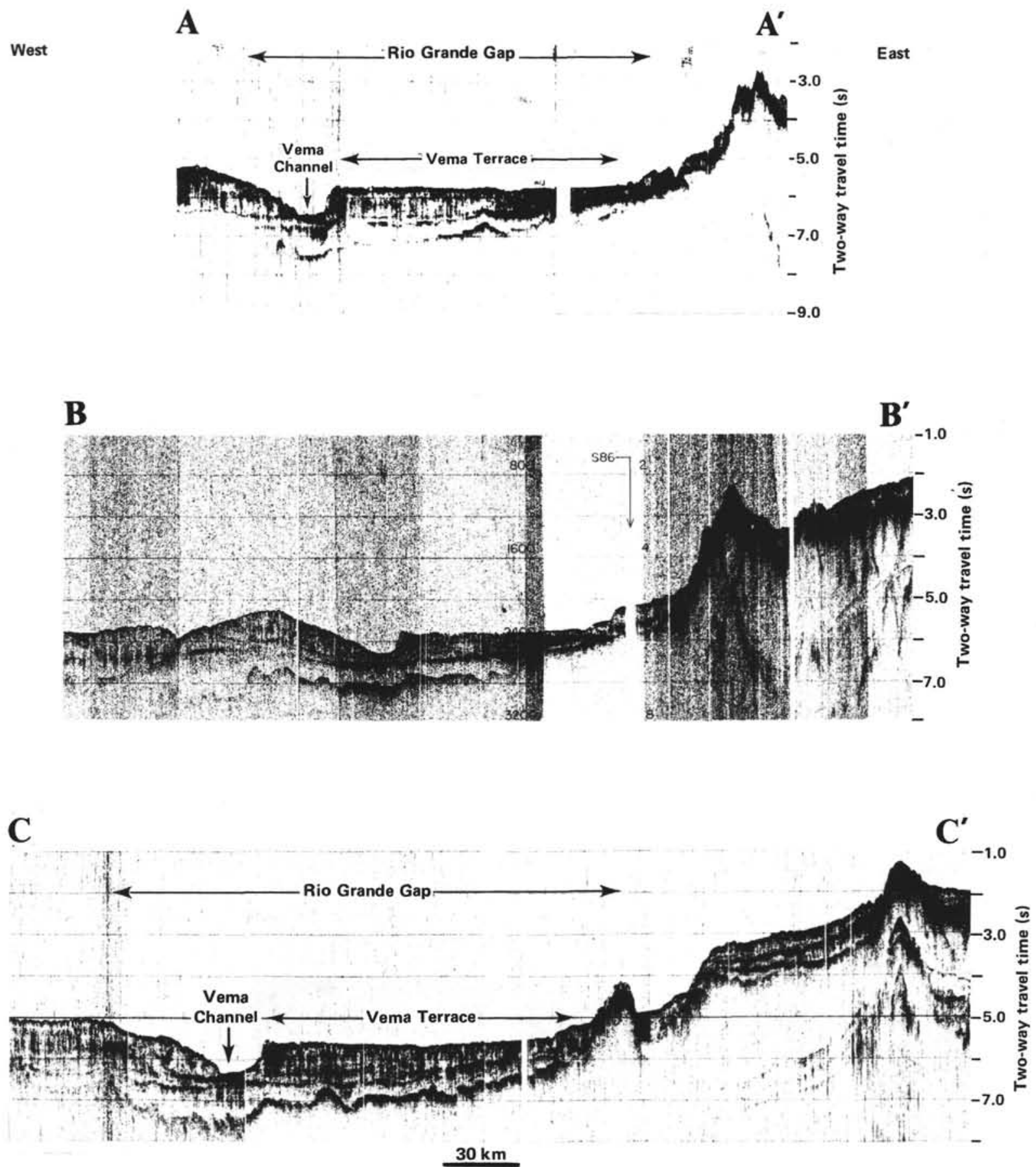

Figure 4. Single-channel seismic profiles across the Rio Grande Gap. Note the broad terrace to the east of the Vema Channel. Vertical exaggeration is about 1:22.

present position of the Vema Channel (Fig. 7). The presence of this buried channel indicates that the basement high has further concentrated the erosional activity responsible for the observed unconformity.

Seismic Sequence B occurs between Unconformity A, described above, and Unconformity B (Table 1 and Fig. 5). Sequence B is generally acoustically transparent and shows only a few discontinuous reflections. In places, however, low-amplitude reflections are observed baselapping Unconformity A along the lower boundary of this sequence. Sequence B thins and pinches out lo- cally beneath the axis of the Vema Channel (Fig. 5). In areas where basement dips to the northeast (at the northern extremity of the Rio Grande Gap), Sequence B thickens (Fig. 8). The upper boundary of Sequence B is a prominent regional reflector and an unconformity as indicated by the downlap of reflections within Sequence C above.

Sequence $\mathrm{C}$ forms the major part of the terrace to the east of the Vema Channel (Table 1 and Fig. 5). Characterized by both channelward-dipping reflections and internally contorted reflections (Figs. 5, 6, 8), this se- 


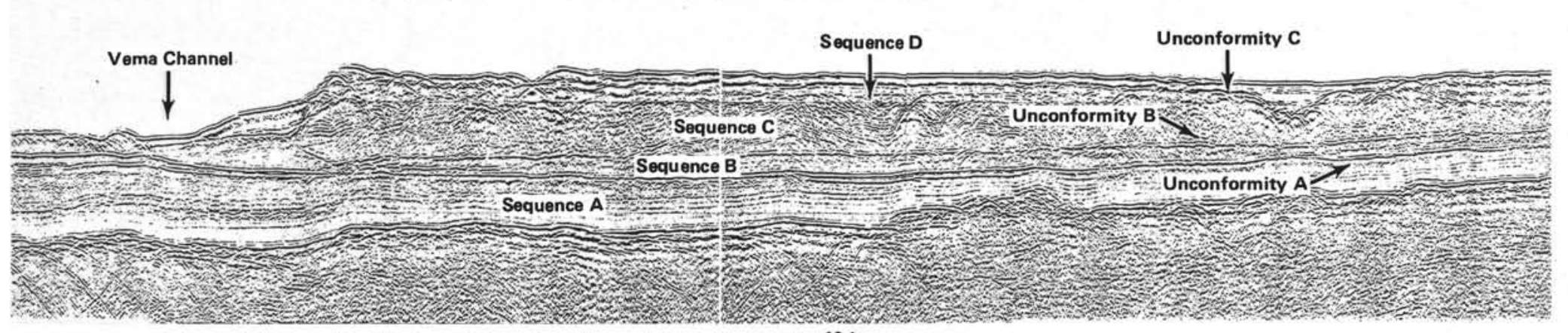

$\sim 10 \mathrm{~km}$

Figure 5. Multichannel seismic profile across the Rio Grande Gap showing the seismic sequences discussed in the text. The basement is fairly smooth and level. Vertical exaggeration is about 1:6.

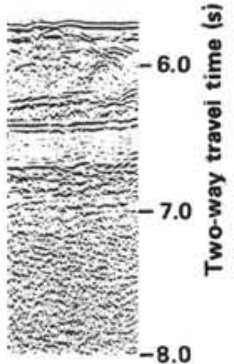

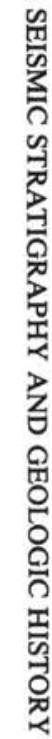


$\mathbf{E}^{\prime}$

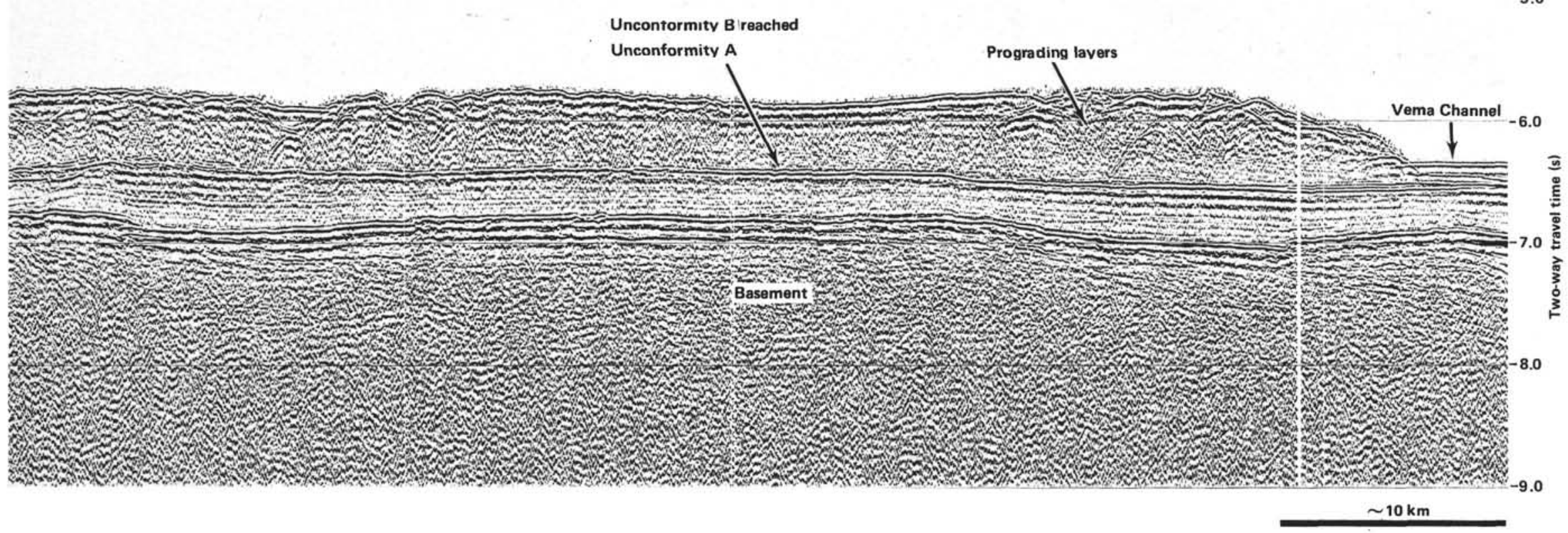

Figure 6. Multichannel seismic profile across the Rio Grande Gap in a region where Sequence B was totally eroded and Unconformities A and B coincide. The dipping reflectors indicate a sedimentary progradation that was responsible for the construction of the terrace along the Vema Channel. Also, the coherent reflections within basement may indicate layering. 
$\mathbf{X}$

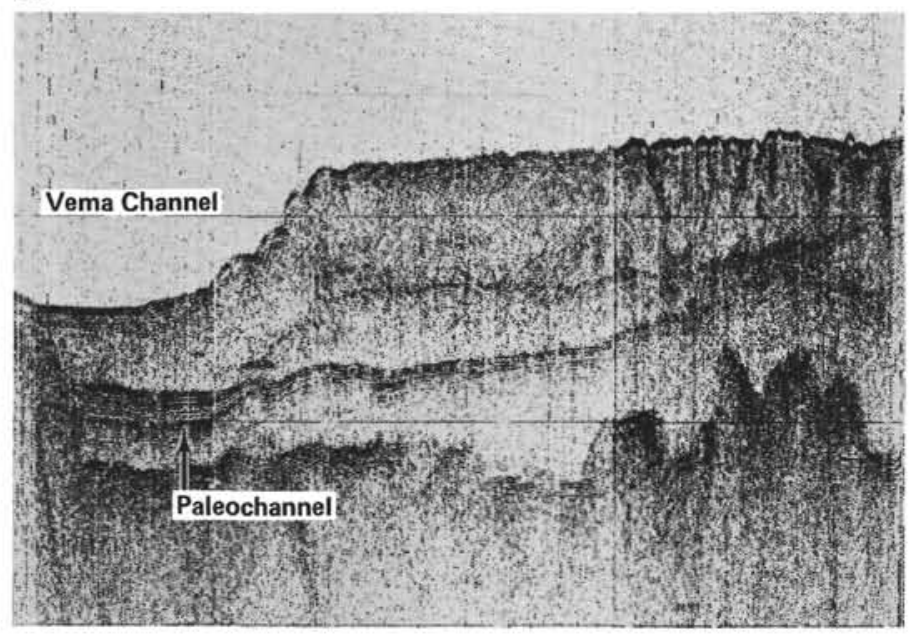

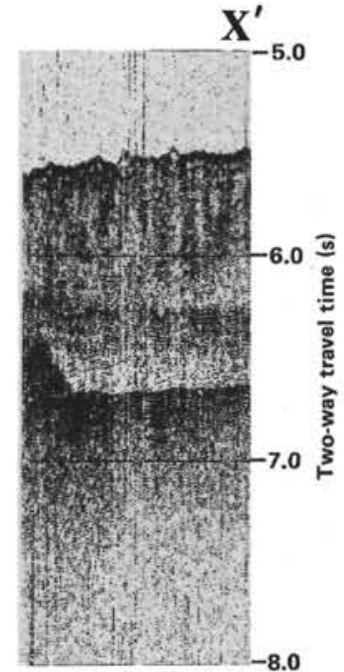
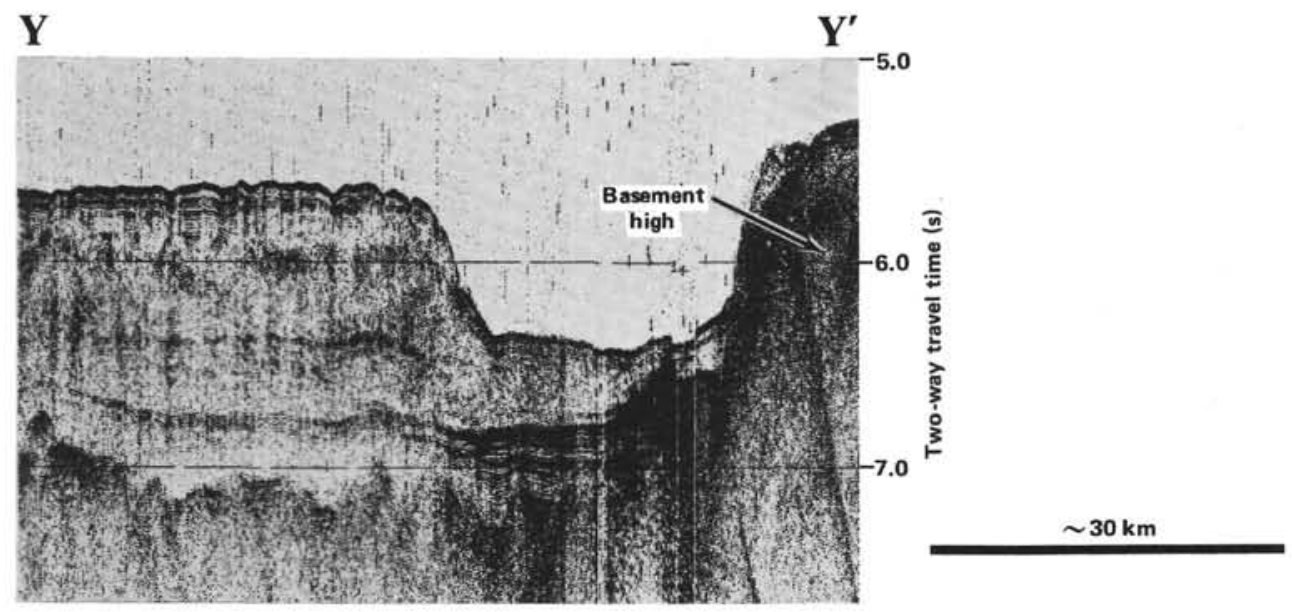

$\mathbf{Z}$

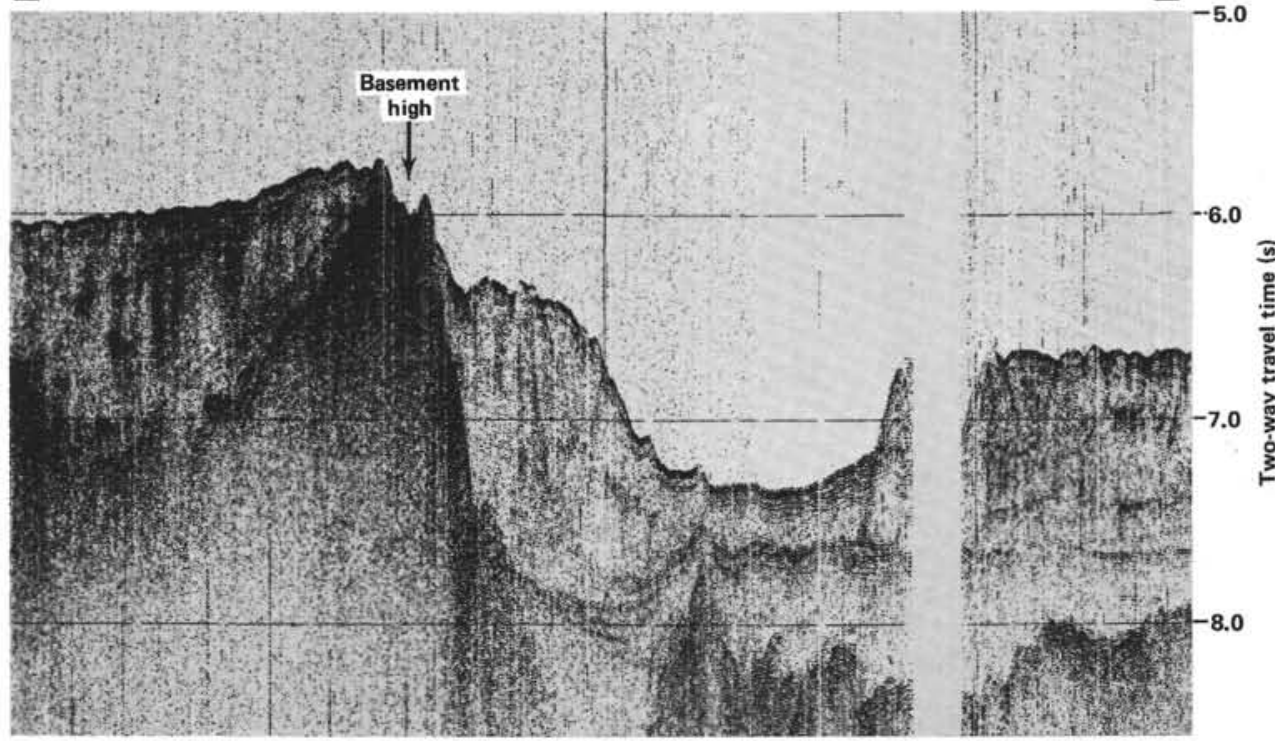

Figure 7. Single-channel seismic profiles showing the paleochannel defined by Unconformity A. This paleochannel is visible only in the region where the basement high to the west of the Vema Channel is prominent. 
G
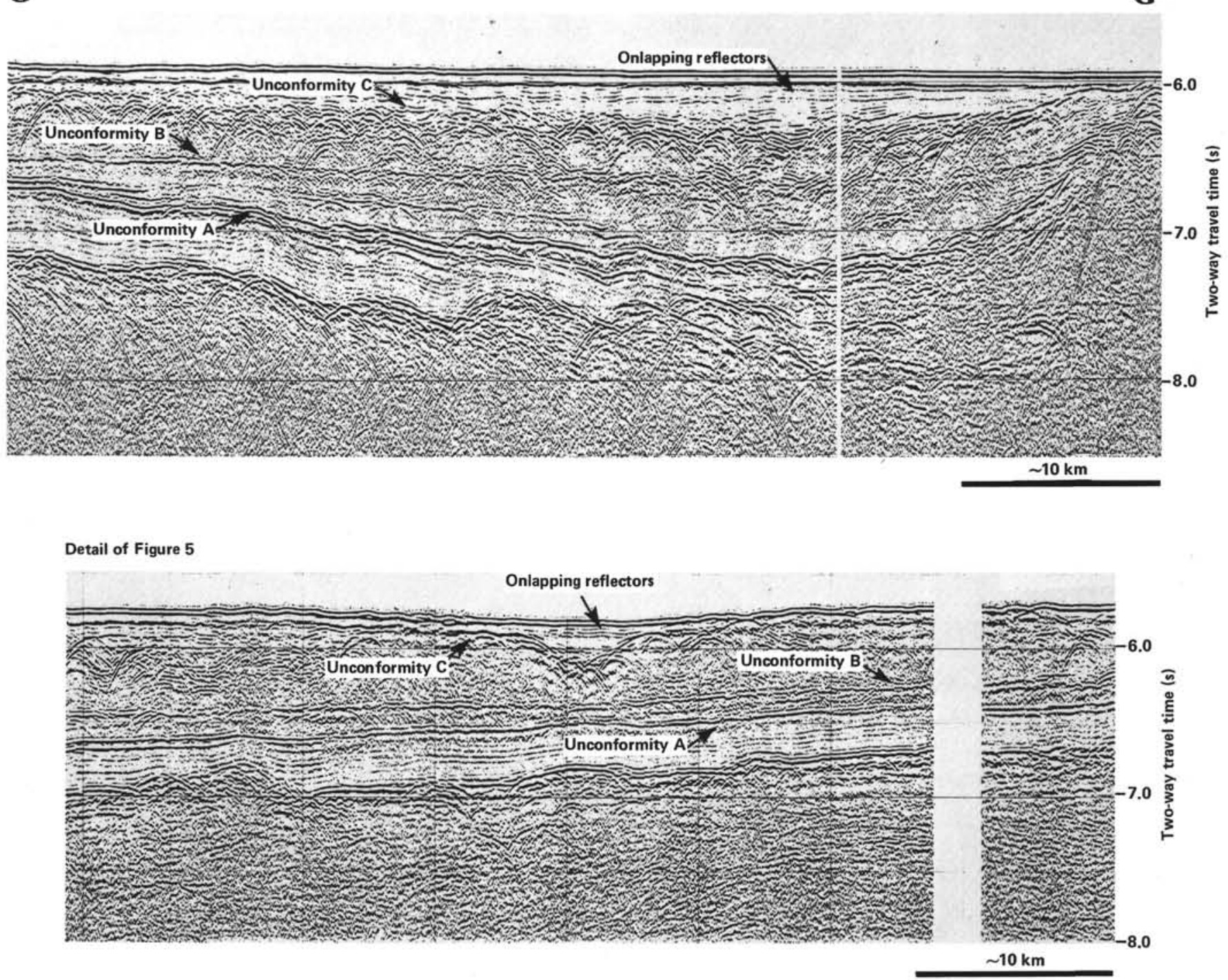

Figure 8. Detail from the multichannel profiles showing the unconformities used to define the seismic stratigraphy of the Rio Grande Gap.

quence in cross section appears somewhat similar in geometry to an alluvial terrace. Sequence $C$ occurs between a level surface at its base (Unconformity B) and an unconformity close to the seafloor (Unconformity C). Unconformity $\mathrm{C}$ is defined by a surface below the seafloor characterized by diffractions, which probably represents an erosional surface. At places, this unconformity cuts into Sequence $\mathrm{C}$ and forms channels (Fig. 8).

Sequence D extends from Unconformity $C$ to the seafloor. A thin sequence, it is in some places hardly distinguishable from the seafloor reverberation. This sequence is characterized by horizontal low-amplitude reflections that are generally parallel to the seafloor. In places where Unconformity $\mathrm{C}$ delineates a channel, Sequence $\mathrm{D}$ fills and onlaps the relief delineated by Unconformity C (Fig. 8).

The following history for the sedimentary evolution of the Rio Grande Gap area is based on the above inter- pretation of the seismic profiles. A major erosional event affected this region and generated a regional unconformity (Unconformity A). Throughout much of the studied area, this unconformity defines a fairly smooth and level surface, and baselapping relationships are hardly distinguishable. At about $29^{\circ} \mathrm{S}$, however, Unconformity A deepens towards the northeast (Fig. 8) and parallels basement. Onlapping is clearly observed above Unconformity A in this region of inclined basement. Unconformity A thus marks a major increase in bottom-water circulation through this studied area.

Sequence B probably represents areally restricted sedimentation in the Rio Grande Gap after the erosional event responsible for Unconformity A. At the top of Sequence B, Unconformity B marks the base of a progradational level and the beginning of a filling episode in the Rio Grande Gap. High sedimentation rates in a highenergy environment accompanied this change, and Sequence $\mathrm{C}$ was deposited. The seismic character of Se- 
quence $\mathrm{C}$, mainly its dipping layers, and its spatial distribution, forming a terrace adjacent to the channel, suggests that it was deposited by the fast northerly flow of AABW water that carried sediments from the Argentine Basin into the Rio Grande Gap and Brazil Basin. These sediments were transported along the bottom, filled the gap, and formed the terrace. The contorted reflections might represent slumping at the channel margins as it prograded to the west.

A younger erosional event affected the top of the prograding sequence and generated Unconformity C. The sediments above this unconformity were probably deposited under the influence of bottom currents as indicated by the onlapping relations observed in places where Unconformity $\mathrm{C}$ forms channels.

\section{Seismic Stratigraphy of the Southern Portion of the Brazil Basin}

Five seismic sequences are defined in the vicinity of DSDP Site 515 (Fig. 1) in the southern part of the Brazil Basin (Fig. 9; Table 1). Sequence I is characterized by relatively low-amplitude, parallel to subparallel internal reflections, which seem to onlap and fill the basement lows. This onlap and fill at the base of Sequence I suggests deposition by distal turbidites and hemipelagic sedimentation. The upper boundary of Sequence $I$ is a prominent unconformity (Unconformity I) that marks a distinct change in the seismic character of the sediments above and below it (Fig. 9). This unconformity is defined by a high-amplitude reflector that truncates the beds of Sequence I and is onlapped by Sequence II above (Fig. 9).

Sequence II is defined between two prominent unconformities (Unconformities I and II; Fig. 9). This sequence is more acoustically transparent than the sequence below it and is characterized by a few subparallel continuous weak reflections. The onlap and fill observed at the base suggests some current activity, rather than just pelagic or hemipelagic sedimentation. Unconformity II, at the top of this sequence, is a prominent regional surface that, in places, truncates considerable thicknesses of Sequence II (Fig. 10) and delineates a broad shallow channel in the vicinity of Site 515 (Fig. 9). This unconformity represents a major erosional event in the southern part of the Brazil Basin.

The thin Sequence III is restricted in occurrence to the area of the broad channel in the vicinity of Site 515 that was eroded by the event responsible for Unconformity II. A few strong and continuous reflections are observed within this sequence. The upper boundary of Sequence III is marked by a prominent flat reflector (Unconformity III, Fig. 9), which merges laterally with Unconformity II, away from the channel.

Sequence IV is defined between Unconformities III and IV (Fig. 9). It is, in general, acoustically transparent, except for some strong hummocky reflections at its base. Sequence IV shows a broad lenslike section in the vicinity of Site 515 (Fig. 9) and suggests a high influx of sediments that formed a broad sedimentary lobe to the north of the Vema Channel (Fig. 9). The lobate configuration of this sequence may represent localized sedi- ment deposits, probably transported to this part of the Brazil Basin by bottom water flowing through the Rio Grande Gap.

The hummocky clinoforms at base of Sequence IV resemble those described by Mitchum and others (1977): "hummocky clinoform configuration consists of irregular discontinuous subparallel reflection segments forming a practically random hummocky pattern marked by non-systematic reflection terminations and slips. This pattern is generally interpreted as strata forming small interfingering clinoform lobes building into shallow water in a prodelta or interdeltaic position." Despite its deep-water location, these hummocky reflections north of the Vema Channel may arise from the same general conditions, in which a localized channel brings a high influx of sediments into a basin and forms deltaic lobes. The basic difference is that the lobes here were deposited at the base of a fanlike deposit formed in an abyssal environment under the influence of a strong bottom current.

Sequence $\mathrm{V}$ is an acoustically transparent interval between Unconformity IV and the seafloor (Fig. 9). It thickens east of Site 515 and forms a smaller fanlike deposit stratigraphically above the larger lobe of Sequence IV. The occurrence of this smaller lobe indicates that, after the formation of Sequence IV, the locus of sedimentation in this part of the Brazil Basin shifted eastward. This shift in the sedimentation was possibly partly a consequence of the relief on the lower lobe (Sequence IV), which redirected the flow of AABW in the southern part of the Brazil Basin.

\section{Correlation between Seismic Data in the Brazil Basin and Site 515}

Drilling at Site 515 ended at $636 \mathrm{~m}$ sub-bottom (see site chapter, Site 515, this volume). Drilling penetrated three of the seismically defined unconformities (Unconformities II, III, and IV) (Figs. 9, 11). Unconformity II corresponds to the contact between Unit 3 and Subunit $2 \mathrm{~b}$ (Fig. 11), marked by a lag deposit of subrounded to subangular grains of fine sand, composed mainly of quartz, fish teeth, glauconite, biotite, and assorted heavy minerals. This unconformity represents a hiatus spanning about $22 \mathrm{Ma}$ between the early Eocene and the middle Oligocene (site chapter, Site 515, this volume).

Unconformity III is a flat surface that can be observed above the channelized area of Unconformity II (Fig. 9). Unconformity III corresponds in depth to the contact between lithologic Subunits $2 \mathrm{~b}$ and 2a (Fig. 11). Subunit $2 \mathrm{~b}$ is below Unconformity III and corresponds to seismic Sequence II. Subunit $2 b$ is a dark greenish gray terrigenous mudstone of late Oligocene age, whereas Subunit $2 \mathrm{a}$ is a dark greenish mudstone of middle Miocene to late Oligocene age. Subunit $2 \mathrm{~b}$ contains layers, $10-15 \mathrm{~cm}$ thick, rich in calcareous microfossils, and intervals barren of calcareous material but rich in fish remains. The calcareous layers always have sharp basal contacts and resemble the Pleistocene-Recent layers interpreted as Rio Grande Rise turbidites (Shor et al., this volume). The layers rich in fish remains might indicate either very slow rates of deposition or erosional condi- 
West

WSA-20

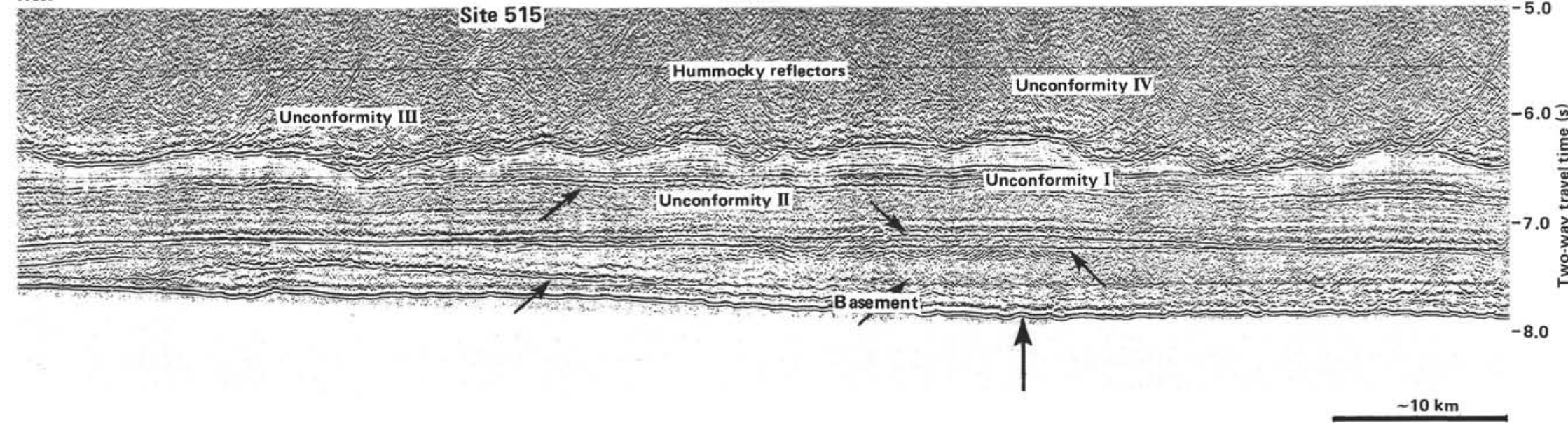

Figure 9. Profile WSA-20, with the projected location of Site 515. Unconformity II defines a broad shallow channel in the region to the north of the Vema Channel (adjacent to Site 515, see Fig. 2 for location of this line), and Sequence III is restricted in occurrence to the region within the broad channel defined by Unconformity II. Outside this area, Unconformity III merges with Unconformity II. Hummocky reflectors are observed above Unconformity III and form the base of a large sedimentary lobe. Site 515 drilled through Unconformity II. 

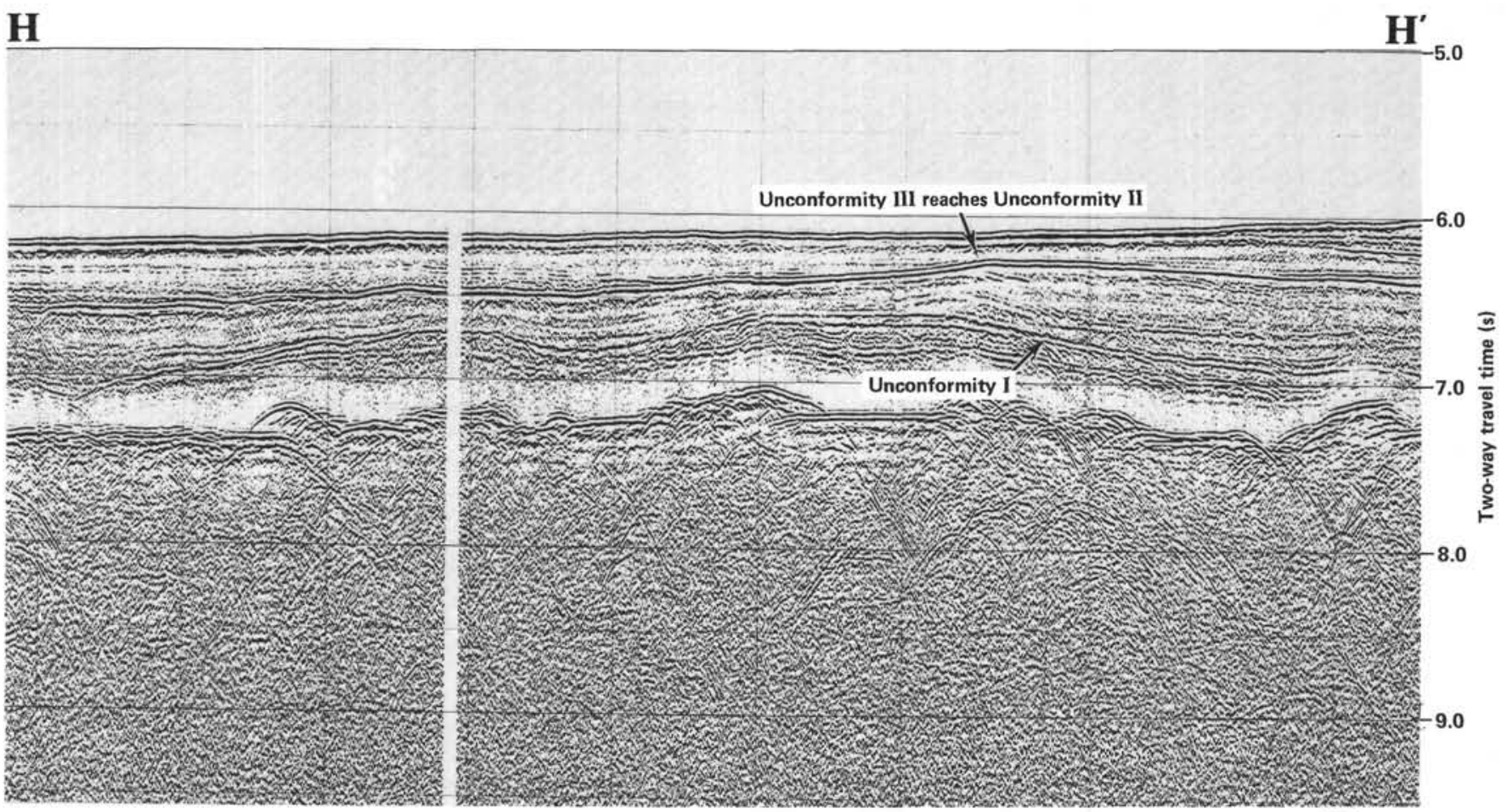

Figure 10. Detail of multichannel seismic profile WSA-18, which connects the Rio Grande Gap with the Site 515 area in the Brazil Basin. The nature of the major reflectors observed at Site 515 area can be inferred here, because both Unconformities I and II truncate the sedimentary sequences, and onlap occurs on both of these reflectors. Outside the area around Site 515, Unconformity III merges with Unconformity II (see Figs. 9 and 12 for comparison).

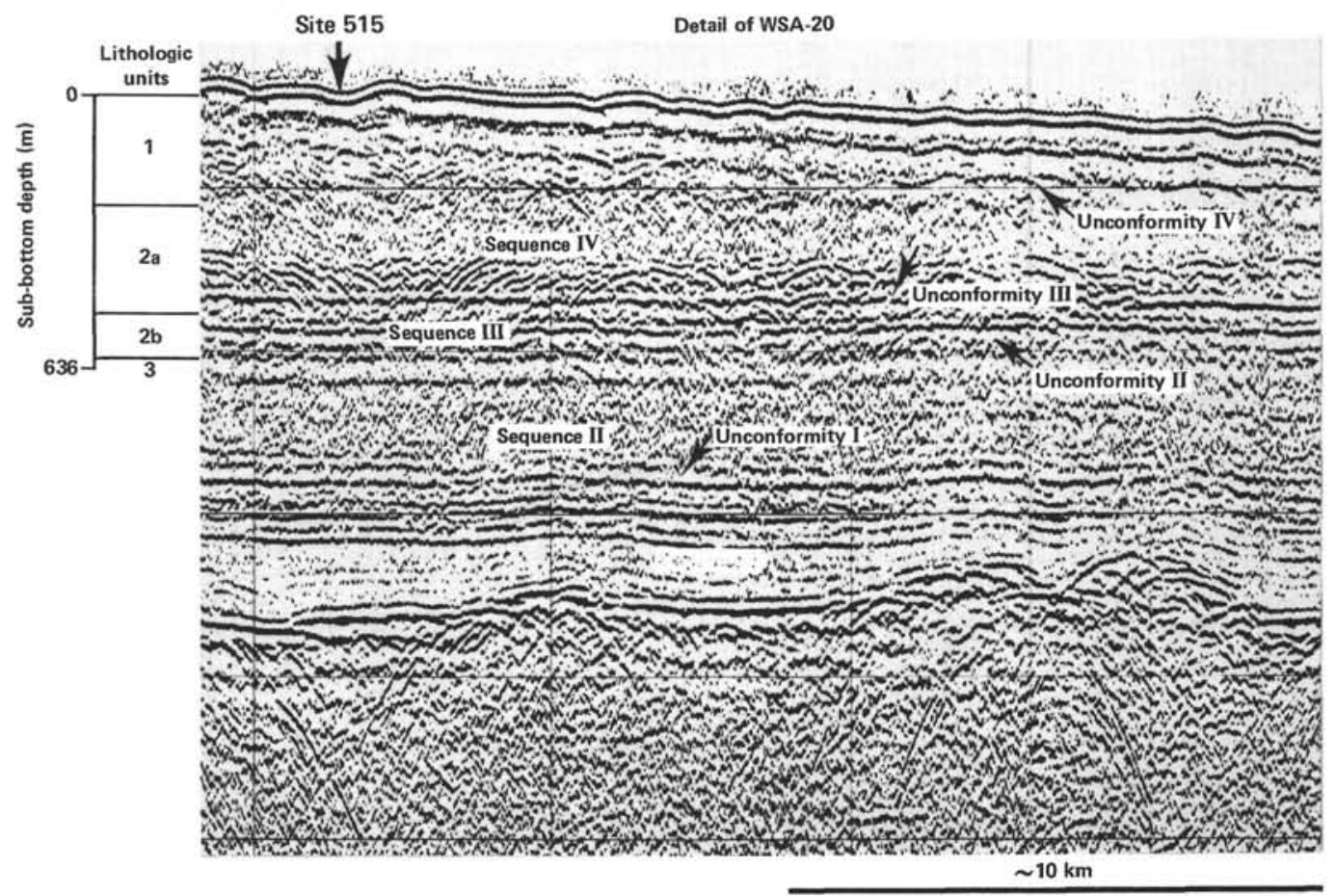

Figure 11. Detail of Profile WSA-20 crossing Site 515 showing the correlation between the seismic sequences and the drilled sedimentary units. Site 515 drilling terminated at $636 \mathrm{~m}$ and only $19 \mathrm{~m}$ were drilled in Lithologic Unit 3. 
tions that removed and/or dissolved the small particles and calcareous shells. Subunit $2 \mathrm{~b}$ lacks the siliceous microfossils that are abundant in Subunit 2a, but does contain rare chert horizons. Although there is a clear lithologic change across Unconformity III (the contact between Subunits $2 \mathrm{a}$ and $2 \mathrm{~b}$ ), the erosional event inferred from this surface must have been of short duration because, so far, no time gap has been detected. The seismic lines show that Subunit 2b (Sequence III) occurs only where Unconformity II defines a broad channel.

Hummocky reflections observed above Unconformity III correspond in depth to the base of Subunit 2a, where rip-up clasts, sedimentary folds, and ripple marks indicate a sedimentary relief generated by bottom currents transporting a heavy load of sediments. These sedimentary features at the base of Subunit 2a support the hypothesis developed from the interpretation of the seismic lines that the high influx of sediments began soon after the formation of Unconformity III. The diatoms and radiolarians found within Subunit $2 \mathrm{a}$ at Site 515 contain reworked components, strongly suggesting bottom-current transport.

Unconformity IV corresponds to the boundary between Units 1 and 2 (Fig. 11). Unit 1 is a grayish brown terrigenous mud of Quaternary to early Pliocene or late
Miocene age. The boundary between these units occurs at $180 \mathrm{~m}$ sub-bottom and probably represents a hiatus from the middle Miocene to early Pliocene.

\section{Correlation of Seismic Stratigraphy in Brazil Basin and Rio Grande Gap}

Although separated by basement highs at the southern margin of the Brazil Basin, the seismic sequences and unconformities in the Brazil Basin dated at Site 515 can be correlated with the seismic sequences observed at the Rio Grande Gap area (Table 1). These basement highs are part of a major lineament, the Rio Grande Fracture Zone (Gamboa and Rabinowitz, 1981), and disrupt the continuity along the two multichannel lines connecting the Brazil Basin to Rio Grande Gap (Fig. 3).

A line drawing of Profile SA-24, shot along the axis of the Vema Channel from the Rio Grande Gap to the region of Site 515, is shown in Figure 12. This profile shows that Unconformity II (the unconformity between Unit 3 and Subunit $2 \mathrm{~b}$ reached at $617 \mathrm{~m}$ sub-bottom at Site 515) becomes shallower towards the Rio Grande Gap and crops out along the axis of the Vema Channel. At the Rio Grande Gap, on several seismic profiles, Unconformity A (the high-amplitude reflector that defines a regional unconformity in this area; Fig. 5) also crops
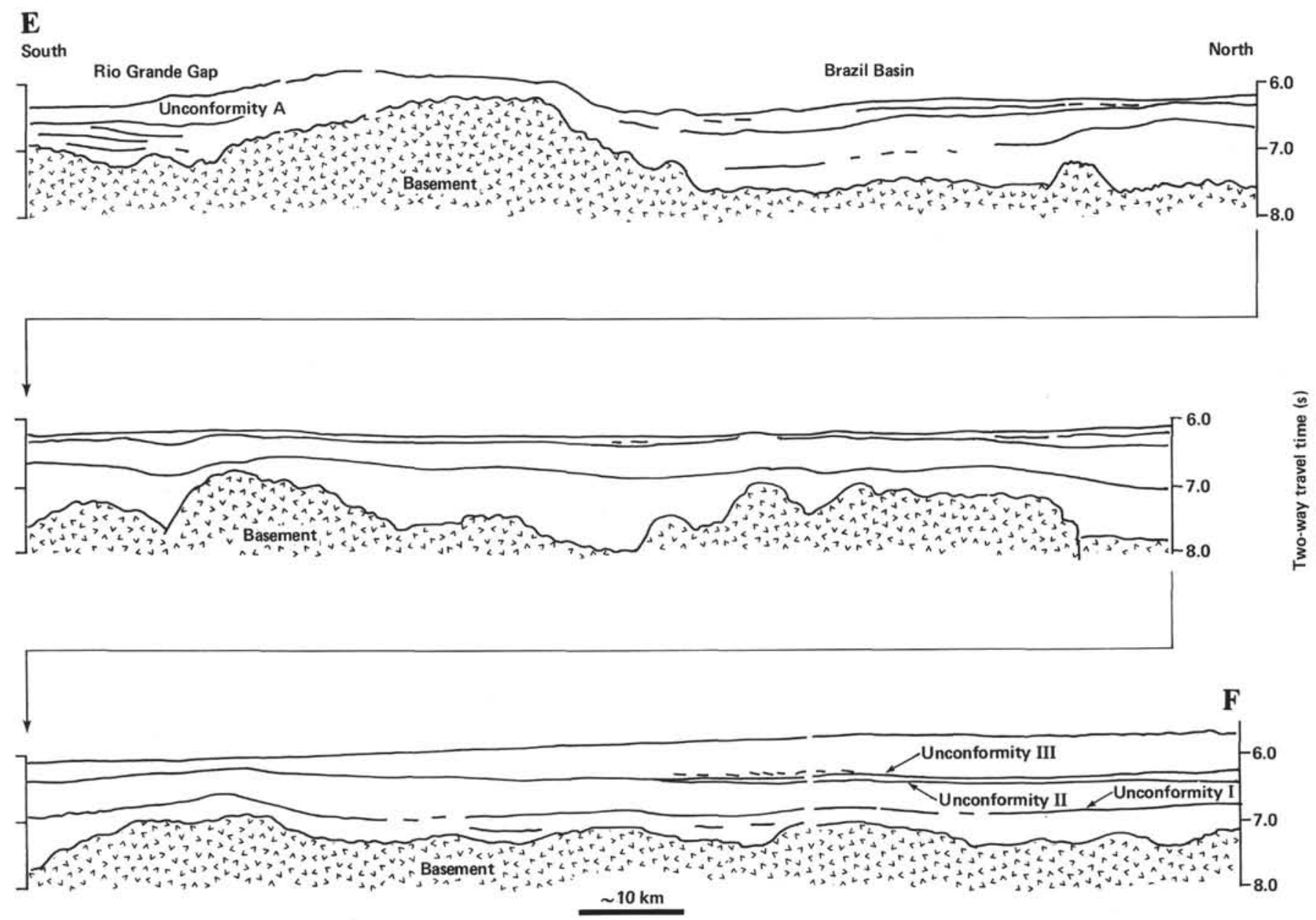

Figure 12. Tracing of Profile SA-24, which connects the Rio Grande Gap with the area of Site 515. Unconformity III merges with Unconformity II. 
out at some locations along the axis of the channel. As exemplified by Profile SA-24, Unconformity II in the Brazil Basin can be correlated with confidence with Unconformity A in the Rio Grande Gap. In addition, the seismic sequences observed above this regional unconformity at the Rio Grande Gap and in the southern Brazil Basin show a close correspondence in their acoustic characteristics (Table 1). Seismic Sequence B at the Rio Grande Gap and Seismic Sequence III in the southern Brazil Basin are suggestive of localized and restricted deposition. As shown by most of the seismic lines, Sequence B pinches out towards the Vema Channel (Fig. 5); and Sequence III occurs only within a broad channel eroded during the event that originated the surface defined by Unconformity II in the Brazil Basin. The upper limits of Seismic Sequences B and III are defined by reflections that mark the beginning of a high influx of sediments into both regions. The prograding layers mark the beginning of the infilling and formation of the terrace at the Rio Grande Gap, and hummocky reflections represent the base of the broad sedimentary lobe within the Brazil Basin. Unconformity IV defines the base of the younger seismic sequence in the area adjacent to Site 515 and is tentatively correlated with Unconformity C in the Rio Grande Gap area. This surface was probably formed during the late Miocene.

The interpretation of the multichannel lines in the Rio Grande Gap and Brazil Basin suggests that both Unconformity A and Unconformity II result from a significant change in circulation dynamics along the ocean floor in these regions. Based on the regional occurrence of these surfaces and on the correspondence of the characteristics of the seismic sequences observed above them in both areas, it is suggested here that Unconformity A at the Rio Grande Gap and Unconformity II at the southern Brazil Basin resulted from the same erosional event.

\section{Discussion}

This study of seismic reflection data in the Rio Grande Gap and the southern Brazil Basin reveals a sedimentary history punctuated by conspicuous erosional and depositional episodes. Some of these episodes are dated by the drilling at Site 515 . Unconformities II and III indicate major changes in bottom-water circulation. Data from Site 515 show that Unconformity II straddles the Eocene/Oligocene boundary and that Unconformity III is late Oligocene in age. Direct evidence for the age of Unconformity I or for the sequence lying between it and basement is not available.

The sedimentary structures in the lower Eocene sediments (see description of Unit 3, Site 515, this chapter) and the existence of an older unconformity (Unconformity I) in the Brazil Basin (see Fig. 9) suggest that some kind of bottom circulation already existed in the region. Unconformity II in the Brazil Basin and Unconformity A at the Rio Grande Gap, however, represented a fundamental change in the circulatory regime that we correlated with the onset of the northward flow of Antarctic Bottom Water (AABW). The onset of AABW is conventionally assumed to have occurred at the Eocene/
Oligocene boundary (Shackleton and Kennett, 1975; Kennett, 1978). Site 515 was intended partly to verify this chronology with the result that the concept of a sharp onset of AABW has been questioned, on the basis of the character of Unit 3 (Barker et al., 1981). An erosional event, however, is marked by an unconformity that seems to be longer than the event itself, and the 22-Ma hiatus at Site 515 hinders any more precise investigation. Site 515 may be useful in delimiting the younger end of this change, because deposition (of Sequence III, the late Oligocene Subunit 2b) resumed earlier there than elsewhere. The reflection profiles show, however, that younger sediments of Sequence II (Unit 3) may be found beneath Unconformity II away from the channel that underlies Site 515 , so that the older limit is poorly constrained. A better opportunity for dating this event may be afforded by drilling the Vema Terrace, east of the Vema Channel in the Rio Grande Gap. Much less promising, although more accessible, are drill sites in the Vema Channel itself, where Unconformity A locally outcrops at the seabed, but also formed a paleochannel where basement topographic constriction intensified erosion, resulting in a hiatus probably even longer than at Site 515 .

The second marked change in depositional regime occurred in the late Oligocene and resulted from a high influx of sediments into the Rio Grande Gap and Brazil Basin. These sediments were transported by bottom currents, as indicated by the prograding layers observed in the Rio Grande Gap and by sedimentary lobes in the region adjacent to Site 515 in the Brazil Basin. The terrace to the east of the Vema Channel and the broad fanlike deposit in the Brazil Basin to the north of the Vema Channel were formed by this high influx of sediment.

A major low stand of sea level during the middle late Oligocene was identified by Vail and others (1977) in the sedimentary sequences at several continental margins of the world. Major global low stands allow the exposure and erosion of large sections of the continental shelves. During the low stands of sea level, sediments derived from the continents bypass the continental shelves and are deposited on the continental rise and in abyssal regions. Global low stands of sea level generally imply a high influx of terrigenous sediments to the deep sea. This global low stand of sea level is tentatively correlated with the high influx of sediments observed at the Rio Grande Gap and in the southern part of the Brazil Basin.

The path of these sediments from the continental shelf to our area of interest, however, was probably not direct. The acoustic character of Sequences IV and C and the nature of Subunit 2a at Site 515 imply their deposition from bottom currents. The siliceous microfossils in Subunit 2a do not establish a southern provenance, but we believe that most of these sediments were transported northward along the bottom as a nepheloid layer within AABW. The late Oligocene low stand of sea level might have caused increased subaerial erosion on the Argentine continental shelf, and subsequent downslope transport by turbidity currents made the fine fraction available for entrainment within the northward- 
flowing $\mathrm{AABW}$ on the lower continental rise. Lesser contributions may have come from the Brazilian margin by a similar process, after recirculation within the Brazil Basin, and from the high productivity region of the Antarctic Circumpolar Current, after Drake Passage opening in the early Miocene or latest Oligocene (Barker and Burrell 1977, 1982). The opening of Drake Passage, however, might have led to the partial disruption of the northward AABW flow by the growing Antarctic Circumpolar Current (Barker and Burrell, 1982), causing a gradual reduction in AABW strength through the Miocene and thus reinforcing the effects of enhanced sediment supply on rates of deposition in the Rio Grande Gap and southern Brazil Basin.

The younger unconformity observed in the southern portion of the Brazil Basin and in the Rio Grande Gap area was probably eroded sometime during the late Miocene. Vail and others (1977) defined two major late Miocene falls of sea level, one at about $11.5 \mathrm{Ma}$ and one at about 6.6 Ma. Because our present stratigraphic control is limited to Site 515 , we cannot firmly associate this unconformity with either one of the proposed falls of sea level.

\section{CONCLUSIONS}

The onset of strong bottom-water circulation in the Rio Grande Gap and southern Brazil Basin is marked by pronounced unconformity. This unconformity marks a hiatus of $22 \mathrm{Ma}$ duration at Site 515. This hiatus includes the conventionally assumed time of initiation of AABW circulation in the Southern Ocean at the Eocene/Oligocene boundary (Shackleton and Kennett, 1975; Kennett, 1978) and thus may have been caused by the beginning of AABW circulation through the Rio Grande Gap and Brazil Basin.

During the initial phase of AABW circulation into this area, the Rio Grande Gap and southern part of the Brazil Basin received only small quantities of sediment. Sometime later, during the late Oligocene, the pattern changed and large amounts of sediment began to be delivered to the region. The morphologic terrace lying east of the Vema Channel and the broad sediment lobe in the Brazil Basin were built by a northward-flowing bottom current that transported large amounts of terrigenous sediment and gradually filled the Rio Grande Gap.

The seismic profiles across the Rio Grande Gap indicate that the morphologic-sedimentologic effects of $\mathrm{AABW}$ have changed with time so that contrasting patterns can be recognized. After the initial widespread erosion, a thin sedimentary unit (Sequence B) was deposited locally in topographic lows. Later, during the late Oligocene, the second pattern of a channel and accompanying channel-marginal terrace underlain by sediment were established. Filling of the Rio Grande Gap began and the Vema Channel was delineated. The channel was localized alongside a prominent basement high that must have constricted the water flow. A large sedimentary lobe was built outward from the channel mouth in the southern portion of the Brazil Basin while the sediments that formed the terrace to the east of the Vema Channel were filling the Rio Grande Gap.

A later erosional event could also be distinguished on the multichannel lines and is dated as late Miocene at DSDP Site 515. After this event, the sediment transported northward by AABW filled the channels eroded above the terrace to the east of the Vema Channel. A smaller sedimentary lobe was formed in the area east of Site 515 .

\section{ACKNOWLEDGMENTS}

We wish to thank the officers, crew, and scientists aboard Vema, Robert D. Conrad, Fred H. Moore, and Glomar Challenger for their assistance and cooperation in gathering the data. We also wish to thank Ms. Patricia Ganey from the University of Texas and Mrs. Milly Giarrantano from the IPOD Data Bank-Lamont-Doherty Geological Observatory, for their collaboration. We thank W. Coulbourn, J. Damuth, M. Truchan, and J. Ewing for reviewing the manuscript and making useful suggestions for improvement. Luiz Gamboa is grateful to Coordenaçào do Aperfeicoamento de Pessoal de Nivel Superior (CAPES) for the financial support during the time of collection and interpretation of the data, and to Center for Marine Crustal Studies, Gulf Science and Technology, for providing the facilities for concluding this work. Mrs. Gabriella Kerty and Mrs. Leah Foshay kindly typed the manuscript.

\section{REFERENCES}

Barker, P. F., and Burrell, J., 1977. The opening of Drake Passage. Mar. Geol., 25:15-35.

1982. The influence on Southern Ocean circulation, sedimentation and climate of the opening of Drake Passage. In Craddock, C. (Ed.), Antarctic Geoscience: Madison, WI (University of Wisconsin Press), pp. 377-385.

Barker, P. F., Carlson, R. L., Johnson, D. A., and Shipboard Scientific Party, 1981. Deep Sea Drilling Project Leg 72: southeast Atlantic paleocirculation and Rio Grande Rise tectonics. Geol. Soc. Am. Bull., 92:294-309.

Damuth, J. E., and Hayes, D. E., 1977. Echo character of the east Brazilian continental margin and its relationship to sedimentary processes. Mar. Geol., 24:73-95.

Ewing, J., Worzel, J. L., Ewing, M., and Windisch, C., 1966. Ages of Horizon A and the oldest Atlantic sediments. Science, 154: $1125-1132$.

Ewing, M., Eittreim, S. L., Ewing, J. I., and LePichon, X., 1971. Sediment transport and distribution in the Argentine Basin, nepheloid layer and processes of sedimentation. Phys. Chem. Earth, 8:51-77.

Ewing, M., Ludwig, W. J., and Ewing, J., 1964. Sediment distribution in the oceans: the Argentine Basin. J. Geophys. Res., 10: 2003-2032.

Gamboa, L. A. P., 1981. Marine geology of the Brazilian continental margin and adjacent oceanic basin between the latitudes of $23^{\circ}$ and $37^{\circ} \mathrm{S}$ [Ph.D. Thesis]. Columbia University, New York.

Gamboa, L. A. P., and Kumar, N., 1977. Synthesis of geological and geophysical data in a $1^{\circ}$ square area around Site 356 , Leg 39 DSDP. In Supko, P. R., Perch-Nielsen, K., et al., Init. Repts. DSDP, 39: Washington (U.S. Govt. Printing Office), 947-954.

Gamboa, L. A. P., and Rabinowitz, P. D., 1981. The Rio Grande Fracture Zone in the western South Atlantic and its tectonic implications, Earth Planet. Sci. Lett., 52:410-418.

Heezen, B. C., and Tharp, M., 1978. General Bathymetric Chart of the Oceans. Canadian Hydrographic Service, Ottawa, Canada, GEBCO 5-12.

Heezen, B. C., Tharp, M., and Ewing, M., 1959. The Floors of the Oceans: I. The North Atlantic: Boulder, CO (Geol. Soc. Am. Spec. Paper 65).

Johnson, D. A., McDowell, S. E., Sullivan, L. G., and Biscaye, P. E., 1976. Abyssal hydrography, nephelometry, currents, and benthic boundary layer structure in the Vema Channel. J. Geophys. Res., $81: 5771-5786$. 
Kennett, J. P., 1978. The development of planktonic biogeography in the Southern Ocean during the Cenozoic. Mar. Micropaleontol., 3:301-345.

Lawrence, J. R., 1979. ${ }^{18} \mathrm{O} /{ }^{16} \mathrm{O}$ of the silicate fraction of recent sediments used as a provenance indicator in the South Atlantic. Mar. Geol., 33:M1-M7.

Ledbetter, M. T., 1979. Fluctuations of Antarctic Bottom Water velocity in the Vema Channel during the last 160,000 years. Mar. Geol., 33:71-89.

Ledbetter, M. T., and Johnson, D. A., 1976. Increased transport of Antarctic Bottom Water in the Vema Channel during the last ice age. Science, 194:837-839.

LePichon, X., Ewing, M., and Truchan, M., 1971. Sediment transport and distribution in the Argentine Basin. Antarctic Bottom Current passage in the Brazil Basin. Phys. Chem. Earth, 8:31-48.

Maurer, H., and Stocks, T., 1933. Wissenschaftliche Ergebnisse der Deutschen Atlantischen Expedition auf dem Forschungs und Vermessungsschiff Meteor 1925-1927 (Vol. 11): Berlin (Walter de Gruyter and Co.), 309.

Melguen, M., and Thiede, J., 1974. Facies distribution and dissolution depth of surface sediment components from the Vema Channel and the Rio Grande Rise (southwest Atlantic Ocean), Mar. Geol., 17:341-353.

Mitchum, R. M., Jr., Vail, P. R., and Sangree, J. B., 1977. Seismic stratigraphy and global changes of sea level. Part 6. Stratigraphic interpretation of seismic reflection patterns in depositional sequences. In Payton, C. E. (Ed.), Seismic Stratigraphy-Applications to Hydrocarbon Exploration: Tulsa, OK (Am. Assoc. Pet. Geol. Mem.), 26:117-133.

Moody, R., Hayes, D. E., and Connary, S., 1979. Bathymetry of the Continental Margin of Brazil. Special Map Series, Catalog 832, Am. Assoc. Pet. Geol., Tulsa, OK.
Shackleton, N. J., and Kennett, J. P., 1975. Paleotemperature history of the Cenozoic and the initiation of Antarctic glaciation: oxygen and carbon isotope analyses in DSDP Sites 277, 279 and 281. In Kennett, J. P., Houtz, R. E., et al., Init. Repts. DSDP, 29: Washington (U.S. Govt. Printing Office), 743-755.

Supko, P. R., Perch-Nielsen, K., et al., 1977. Init. Repts. DSDP, 39: Washington (U.S. Govt. Printing Office).

Tucholke, B. E., 1979. Relationships between acoustic stratigraphy and lithostratigraphy in the western North Atlantic Basin. In Tucholke, B. E., Vogt, P. R., et al., Init. Repts. DSDP, 43: Washington (U.S. Govt. Printing Office), 827-846.

Vail, P. R., Mitchum, R. M., Jr., and Thompson, S., III, 1977. Seismic stratigraphy and global changes of sea level. Part 4. Global cycles of relative changes of sea level. In Payton, C. E. (Ed.), Seismic Stratigraphy-Applications to Hydrocarbon Exploration: Tulsa, OK (Am. Assoc. Pet. Geol. Mem.), 26:83-87.

Wright, W. R., 1970. Northward transport of Antarctic Bottom Water in the western Atlantic Ocean, Deep-Sea Res., 17:367-371.

Wüst, G., 1936. Stromges Schwindigkeiten and Stromengen in den Tiefen des Atlantischen Ozeans. In Defant, A. (Ed.), Wissenschaftliche Ergebnisse der Deutschen Atlantischen Expedition Meteor, 1925-1927 (Vol. 6, pt. 2): Berlin, Leipzig (Walter de Gruyter and Co.), 261-420.

Zimmerman, H. B., Supko, P. R., and McCoy, F. W., 1979. Acoustic horizons in the Argentine Basin, southwestern Atlantic Ocean, new evidence from deep-sea drilling. Geology, 7:45-48.

Date of Initial Receipt: August 16, 1982 